\title{
What is the Frequency of Internet Searches by Patients with Rheumatic Diseases? To What Degree are the Websites They Get Information from Reliable and What is the Effect of These Websites on Their Treatment?
}

\author{
Romatizma Hastalarının Hastalık Araștırması Internet Kullanım Sıklığı Nedir? \\ Hastalıklarıyla İlgili Bilgi Aldıkları İnternet Siteleri Ne Kadar Güvenilir ve Tedavi \\ Üzerine Etkisi Nedir?
}

(D) Aysel Gürcan Atçi', (1) Sena Tolu²

1Baltalimanı Metin Sabancı Bone and Joint Diseases Training and Research Hospital, Clinic of Physical Medicine and Rehabilitation, İstanbul, Turkey ${ }^{2}$ Medipol University Faculty of Medicine, Department of Physical Medicine and Rehabilitation, İstanbul, Turkey

\begin{abstract}
Introduction: This study aimed to determine internet use among a certain number of patients with regard to the three prevalent rheumatic diseases in clinical practice and more importantly to evaluate the quality of information available on the internet using the DISCERN scoring system.

Methods: The study population consists of patients with rheumatoid arthritis, ankylosing spondylitis and fibromyalgia. As part of this study, we conducted a survey and recorded whether or not they researched over the internet concerning their diseases. After the survey, we also tested the reliability of the websites. We analysed websites using the DISCERN scoring system in order to determine to what degree these websites contained sufficient.
\end{abstract}

Results: We found that 102 out of 173 cases (58.9\%) used the internet to get information about their disease, while 71 cases (41.04\%) did not conduct any internet research. According to the DISCERN scoring, the aforementioned websites were evaluated with 15 questions in the survey. Consequently, it was inferred that among these websites, 24 (27.2\%) had high-level (4 to 5 points), 44 (50\%) had medium-level (2 to 3 points) and $20(22.7 \%)$ had poor-level (1 point) quality and reliability.

Conclusion: The digital interest that has gradually increased in the recent years has become a concern as patients desire to have information on the course and treatment of their rheumatic diseases. It should be acknowledged that patients with long-term treatment and follow-up processes are not and will not be guided only by their doctors. Physicians may improve the quality of life of their patients and help them

\section{$\ddot{0} Z$}

Amaç: Bu çalışmanın amacı poliklinikte takipli romatoloji hastalarının hastalıklarının tedavisi hakkında internette araștırma yapma oranlarını, internetin hastaların tedavi ve takiplerine etkisini araştırmak ve hastaların rehber olarak kullandıkları internet sitelerinin güvenilirliklerini belirlemektir.

Yöntemler: Çalışma popülasyonu romatoid artrit, ankilozan spondilit ve fibromiyaljili hastalardan oluşmaktadır. Bu çalışmanın bir parçası olarak, anket yapılmış ve internet üzerinden hastalara hastalıkları hakkında araștırma yapıp yapmadıklarını kayıt altına alınmıștır. Anket yapıldıktan sonra, web sitelerinin güvenilirliğini de test edilmiștir. Bu web sitelerinin hastalıklarla ilgili ne derece yeterli ve güvenilir bilgi içerdiğini belirlemek için DISCERN puanlama sistemini kullanarak web sitelerini analiz edilmiștir.

Bulgular: Yüz yetmiş üç romatoloji hastasının geneline baktığımızda 102 olgu $(\% 58,9)$ hastalığı hakkında bilgi almak için interneti kullanırken, 71 olgu $(\% 41,04)$ internette araștırma yapmamıștı. DISCERN skorlamasında, ankette bulunan 15 soru eșliğinde internet siteleri değerlendirildiğinde 24'ü $(\% 27,2)$ yüksek düzey (4-5 puan), 44'ü (\%50) orta düzey (2-3 puan), 20'si $(\% 22,7)$ kötü düzey (1 puan) kaliteye ve bilgi güvenilirliğine sahipti.

Sonuç: Dijital ilgi, romatizmal hastalıkların seyri ve tedavisini irdelemek isteyen hastalar tarafından da kullanılmaktadır. Uzun soluklu tedavi ve takip süreci olan bu hastaların yönlendirilmesinde, günümüzde ve gelecekte sadece doktor kontrolü altında olamadığının bilinmesi ve mevcut websitelerinin gerek sağlık bakanlığı gerekse ilgili dernekler

Cite this article as/Atıf: Gürcan Atçı A, Tolu S. What is the Frequency of Internet Searches by Patients with Rheumatic Diseases? To What Degree are the Websites They Get Information from Reliable and What is the Effect of These Websites on Their Treatment?. Istanbul Med J 2020; 21(4): 275-80.

(c) Copyright 2020 by the University of Health Sciences Turkey, Istanbul Training and Research Hospital/istanbul Medical Journal published by Galenos Publishing House.

(C) Telif Hakkı 2020 Sağlık Bilimleri Üniversitesi istanbul Ĕgitim ve Araştırma Hastanesi/Istanbul Tıp Dergisi, Galenos Yayınevi tarafından basılmıștır. 
avoid unnecessary anxieties, if they regard the foregoing when they inform and instruct them.

Keywords: DISCERN, information reliability, internet, fibromyalgia, rheumatoid arthritis, ankylosing spondylitis tarafından sıkı denetim altında tutulması ile hastaların yanlış bilgilendirilmesi ve yönlendirilmesinin önüne geçilebilir.

Anahtar Kelimeler: DISCERN, bilgi güvenirliliği, internet, fibromyalji, romatoid artrit, ankilozan spondilit

\section{Introduction}

Rheumatic diseases are frequently encountered in physical medicine and rehabilitation practices. The common rheumatic diseases in society are ankylosing spondylitis (AS), rheumatoid arthritis (RA) and fibromyalgia (FM). Among the patients with spondyloarthritis, AS is most common, affecting between $0.15 \%$ and $1.8 \%$ of the white population (1). However, RA -a seropositive disease- has a prevalence of $0.5 \%-1.0 \%$ in most of studies conducted in northern Europe and North America (2). In the general population, the prevalence of FM is defined to be $2 \%-4 \%$ according to the diagnostic criteria used (3).

The patients with rheumatic diseases should be regularly checked by physicians in order to initiate proper treatment for each case; monitor the efficiency, adverse effects and disease-associated complications of treatment; apply exercise and rehabilitation treatments for possible complications and ensure that these treatments become persistent.

In Turkey, 67\% (81 million) of the population are internet users, whereas only $53 \%$ of the world uses the internet $(4,5)$. However, it is observed that patients do not primarily approach medical professionals, but seek guidance from physicians only after making an internet search and being directed by the information provided on websites. This is because the frequency of the use of tablets and smartphones has increased over the last 20 years due to technological developments and ease of internet access $(6,7)$. In the United States, $63 \%$ of internet users turn to the internet when they are faced with a health issue (7). There are more than 70,000 websites in the United States that provide information about health (8). Although such information is of vital importance to patients, many accessible sources fail to provide correct and comprehensive information and the readability rate of quality sources is low $(9,10)$. The reason for low readability is that quality websites do not provide information at a language level that is familiar to the general population. While informing about the treatment of diseases, some websites may claim that a certain treatment choice prevails over the others, if they have a financial interest in it.

This study therefore aimed to determine the frequency of internet use of a certain number of patients with regard to the three most prevalent rheumatic diseases in clinical practice and more importantly to evaluate the quality of information available on the internet using the DISCERN scoring system.

\section{Methods}

The study population consisted of patients with RA, AS and FM, which are the three most common rheumatic diseases in clinical practice. Diagnosis of the patients was made using the ACR/EULAR 2010 criteria for RA (11), the 1984 modified New York criteria for AS (12) and the 1990 ACR classification criteria for FM (13).

As part of this study, we conducted a survey and recorded the age, gender, follow-up period, medication compliance, exercise habit, employment status and whether or not they searched the internet concerning their disease. Subsequently, we determined the proportion of internet use for each rheumatic disease according to the education level. Information was provided while taking the pain scores of patients and conducting a survey on the internet. Written consent was not obtained because the detailed medical and identifiable information of patients were not collected.

After the survey, we also tested the reliability of the websites used by these patients. An internet search was made on Google -the most popular search engine in Turkey and all over the world $(14,15)$. We typed "RA treatment", "FM treatment" and "AS treatment" in the search engine in Turkish and analysed the first three pages and 30 websites using the DISCERN scoring system in order to determine to what degree these websites contained sufficient and reliable information concerning these diseases (16).

The DISCERN scoring system consisted of 15 key questions (Table 1a) and each question was scored from 1 to 5 . The researcher evaluated a given

\section{Table 1a. The DISCERN ${ }^{\circledR}$ instrument}

Question 1: Are the aims clear?

Question 2: Does it achieve its aims?

Question 3: Is it relevant?

Question 4: Is it clear what sources of information were used to compile the publication (other than the author or producer)?

Question 5: Is it clear when the information used or reported in the publication was produced?

Question 6: Is it balanced and unbiased?

Question 7: Does it provide details of additional sources of support and information?

Question 8: Does it refer to areas of uncertainty?

Question 9: Does it describe how each treatment works?

Question 10: Does it describe the benefits of each treatment?

Question 11: Does it describe the risks of each treatment?

Question 12: Does it describe what would happen if no treatment is used?

Question 13: Does it describe how the treatment choices affect the overall quality of life?

Question 14: Is it clear that there may be more than one possible treatment choice?

Question 15: Does it provide support for shared decision-making?

Question 16: Based on the answers to all of the above questions, rate the overall quality of the publication as a source of information about treatment choices. 
website according to the questions and assigned a score from 1 to 5 (Table 1b). The $16^{\text {th }}$ question attempted to reveal the total score and the reliability of a given website. Each website was separately evaluated by two researchers, independent of the other websites. The study protocol was approved by the İstanbul Medipol University Ethics Committee (decision number: 158, date: 22/02/2019).

\section{Statistical Analysis}

Data were analysed using the IBM SPSS for Windows version 23.0 software (IBM Corp. Armonk, NY, USA). Frequency, percentage, mean, standard deviation, minimum and maximum were used for descriptive statistics. A value of $p<0.05$ was considered statistically significant.

\section{Results}

This study included 73 patients (68 females and 5 males) with RA, between the ages of 26 and 73 and with a mean age of $53.47 \pm 10.17$ years. Sociodemographic and disease-related characteristics of the patients are described in Table 2. The mean follow-up period was $9.28 \pm 6.18$ years (range 5 months-30 years). Ninety-one percent used anti-rheumatic drugs. Fifty-four (73.9\%) patients came for follow-up visits regularly. Of the patients, 34 (46.4\%) had searched the internet concerning their disease (Table 2).

Fifty-six patients (52 females and 4 males) with FM, between the ages of 27 and 69 and with a mean age of $44.03 \pm 1.11$ years were enrolled into the study. The mean follow-up period was $6.78 \pm 0.72$ years (range 7 months-20 years). Forty-eight (85.7\%) patients took medication for FM treatment and 32 (57.1\%) patients complied with their follow-up visits. Forty-four (78.4\%) patients did not do exercises regularly. Thirty-nine (69.6\%) patients had conducted internet searches about FM (Table 2).

Forty-four patients (26 female and 18 males) with AS, between the ages of 21 and 72 and with a mean age of $40.02 \pm 1.70$ years were included in the study. The mean follow-up period was $9.45 \pm 0.94$ years (range 1 month- 0 years). Forty (91\%) patients took medication for AS treatment and $32(72.7 \%)$ patients complied with their follow-up visits. Half of the patients (50\%) did exercises regularly. Twenty-nine (66\%) patients had carried out internet searches about AS (Table 2). In total, we found that 102 (58.9\%) patients out of 173 had used the internet to get information about their disease, whereas 71 (41.04\%) patients did not make any search.

\section{Table 1b. The DISCERN ${ }^{\circledR}$ Instrument-results}

\section{Low}

Serious or extensive shortcomings

1

\begin{tabular}{|l|}
\hline \\
\hline 2
\end{tabular}

\begin{tabular}{|l|}
\hline Moderate \\
\hline Potentially important but \\
no serious shortcomings \\
\hline 3
\end{tabular}

High

Minimal shortcomings

5

Table 2. Sociodemographic and disease-related characteristics of the patients

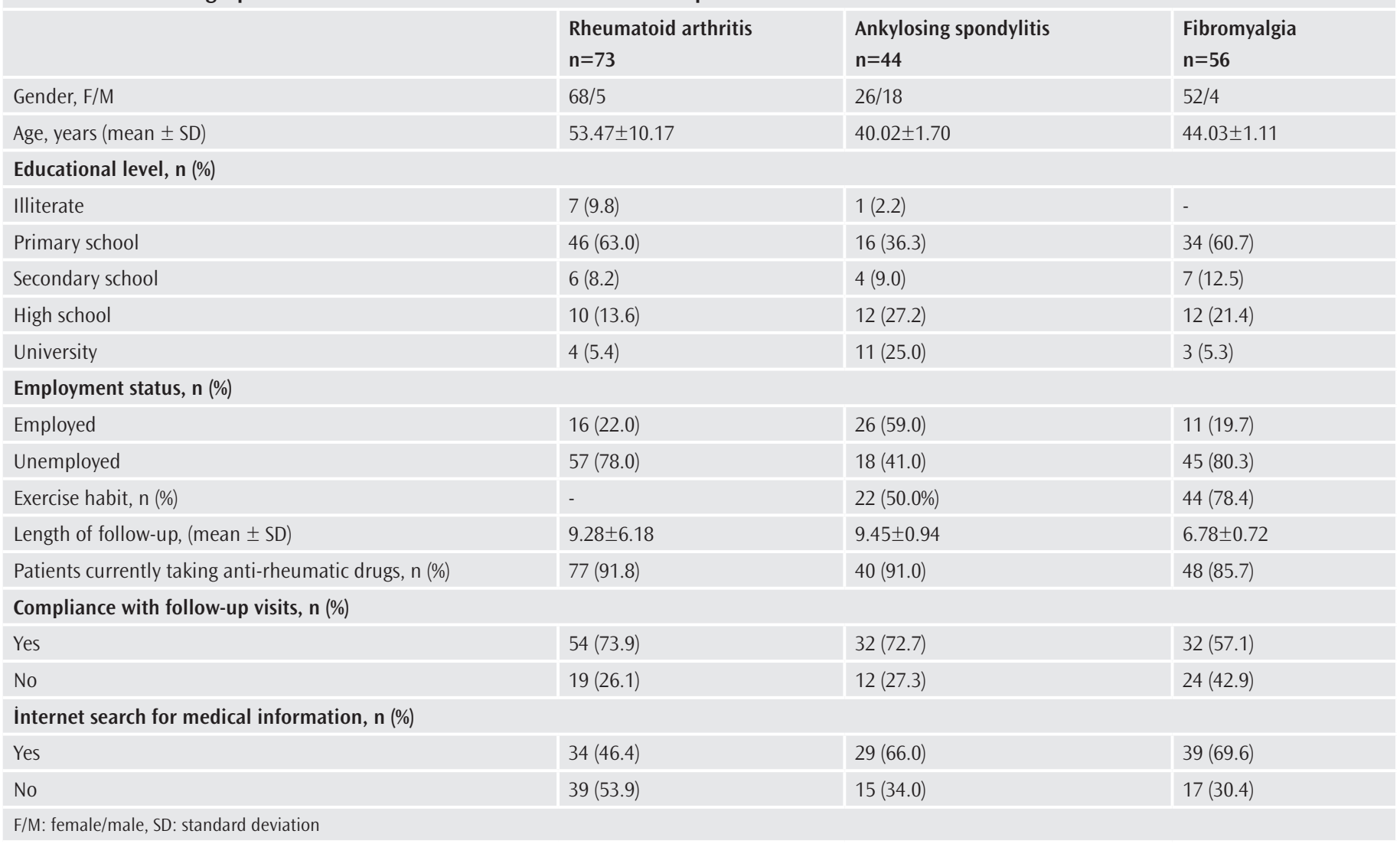


The rate of the internet searches for the rheumatic diseases according to educational levels are shown in Graphic 1. The rate of medication use, follow-up compliance and exercise habits of the patients according to internet use are shown in Graphic 2. The question concerning exercise was only addressed to the patients with FM and AS.

We determined to what degree the websites containing information on RA, FM and AS hosted sufficient and reliable information by using the DISCERN scoring system. Out of 90 websites, 88 were used for the analysis because the other 2 websites were inaccessible. According to the search results, the top two were the websites of health institutions and physicians (Table 3). In the first part of the DISCERN scoring

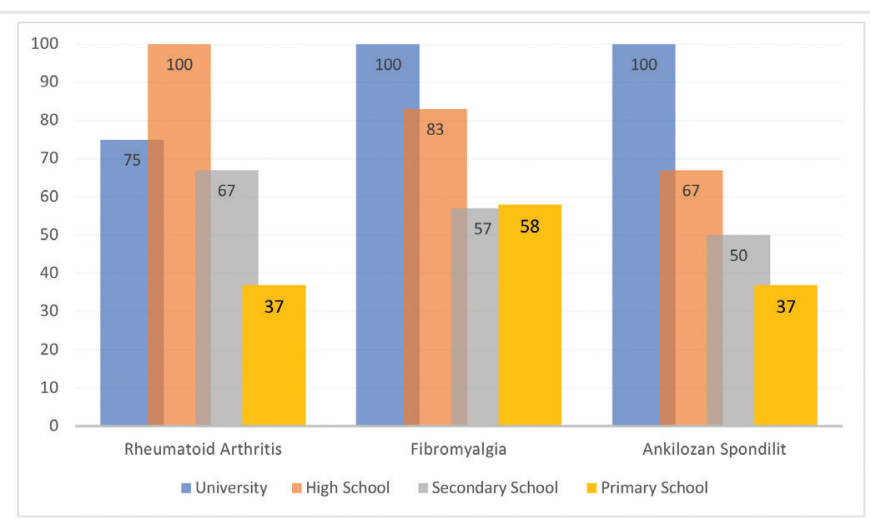

Graphic 1. The rate of internet searches for the rheumatic diseases according to educational levels

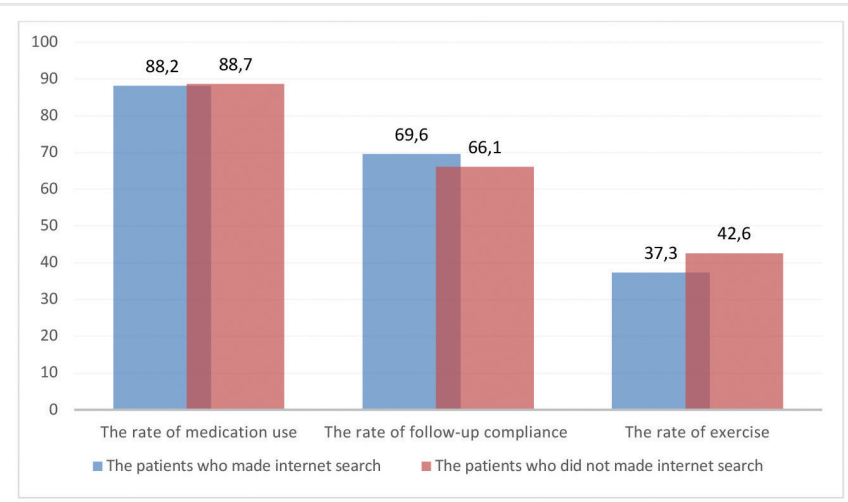

Graphic 2. The rate of medication use, follow-up compliance and exercise habits of the patients according to internet use

Table 3. Website author classification and author definition

\begin{tabular}{|l|l|l|}
\hline $\begin{array}{l}\text { Author } \\
\text { Classification }\end{array}$ & Definition & Number (\%) \\
\hline Healthcare & $\begin{array}{l}\text { Websites affiliated with a } \\
\text { government or private healthcare } \\
\text { facility }\end{array}$ & $27(30.6 \%)$ \\
\hline News & $\begin{array}{l}\text { Websites affiliated with } \\
\text { organisations dealing with news }\end{array}$ & $21(23.8 \%)$ \\
\hline Personal & $\begin{array}{l}\text { Non-physicians with no } \\
\text { institutional or organisational } \\
\text { affiliation }\end{array}$ & $13(14.7 \%)$ \\
\hline Physician & $\begin{array}{l}\text { Individual physicians with no } \\
\text { healthcare facility affiliation }\end{array}$ & $24(27.2 \%)$ \\
\hline Unidentified & $\begin{array}{l}\text { Dead links or otherwise } \\
\text { unidentifiable websites }\end{array}$ & $3(3.4 \%)$ \\
\hline
\end{tabular}

system, 79 (89.7\%) websites out of 88 clearly defined their purpose, the information they contained or to whom they were addressed. On the contrary, only 59 (67\%) websites could achieve their purpose of enlightening the patients about the treatment of rheumatic diseases. of these, 24 (27.2\%) websites could provide appropriate and accurate answers to the possible questions which might be raised by patients with rheumatic diseases. Only 15 (17.0\%) websites gave references that the information provided was proven, whereas $13(14.8 \%)$ indicated the reference publication and website revision dates. The information was consistent and neutral only on 20 (22.7\%) websites. These benefited from many sources of information that were neutral and evaluated multiple treatment choices, weighing their pros and cons. However, only 8 (9\%) websites directed users to other sources which could provide more detailed information concerning the treatment of rheumatic diseases.

In the second part of the DISCERN scoring system, it was inferred that $11(12.5 \%)$ websites out of 88 provided descriptions of how the recommended treatment methods exerted their effect on the body. There were 6 (20.6\%) websites for RA, 2 (6.6\%) for AS and 2 (6.6\%) for FM that gave detailed information on the benefits of each treatment method and only 10 (11.3\%) websites in total, enlightened users about the risk of treatment. There were 22 (25\%) websites that informed about the conditions which may arise if the patients with rheumatic diseases avoided or postponed their treatment. On the contrary, only 9 (10\%) websites stated how treatment options changed the quality of life, what may arise in time and what may be the effects on family and friends. Forty-one (46.5\%) websites expressed that there might be other treatment options for the three rheumatic diseases. Similarly, 25 (28.4\%) websites gave descriptive information, which suggested that patients should seek help from their circle and health professionals in order to choose a treatment regime.

In the third part of the DISCERN scoring system, the aforementioned websites were evaluated using 15 questions in the survey. Consequently, it was inferred that of these websites, 24 (27.2\%) had high-level (4-5 points), 44 (50\%) had medium-level (2-3 points) and 20 (22.7\%) had poorlevel (1 point) quality and reliability.

\section{Discussion}

After being diagnosed with one of the three rheumatic diseases, the treatment processes of many patients continue throughout their lifetime. The longevity of treatments, density of medications, adverse effects that may appear because of medications and misguidance by their circle lead patients to seek alternative treatment methods and conduct internet search, which is the most easily accessible tool today. Indeed, 58\% of the patients we monitored had made an internet search concerning their disease. In our study, the rate of conducting research over the internet in the FM patient group was the highest (69.6\%) and the desire to learn associated with the disease in these patients could be attributed to the more common occurrence of obsessive personality structure in patients with FM compared to the general population (17).

Search engines are used to seek information over the internet. As a search engine, Google is used by more than $90 \%$ of internet users (14). It is observed that internet users generally evaluate the first three pages 
and the top 30 websites when they carry out a search on any subject (18). In this study, we evaluated the top 90 websites from the first three pages that appeared on the search engine when we typed each of the aforementioned rheumatic diseases. Out of 90 websites, 88 were used for the analysis. The other 2 websites were inaccessible. However, it would have contributed to the reliability if other search engines were included and if 50 websites were scanned for each of the three diseases. In addition, the words typed by the patients in the search engine when they carried out a searched for their rheumatic disease is not clearly known. Keywords such as soft-tissue rheumatism, inflammatory articular rheumatism and inflammatory AS might have been used. In this study, we scanned Turkish websites in consideration of the patients.

According to the DISCERN scoring system, these websites had highlevel (27.2\%), medium-level (50.0\%) and poor-level (22.7\%) quality and reliability. The results demonstrated that the top two were the websites of health institutions and physicians. Nevertheless, it could be more revealing to examine the reliability and sufficiency of the websites according to their writers. In another study, physicians' personal websites showed that their ratings were higher than others (19).

As a result of the surveys that we applied to the 173 monitored patients with rheumatic diseases after website evaluations, it was seen that 102 (58.9\%) patients used the internet in order to get information about their diseases. However, it was also established that internet use did not affect the follow-up of these patients who had to be checked regularly. Similarly, there was no significant difference in the rates of medication use. Exercise level -an important factor especially in the treatment of AS and FM- was 37.3\% among internet users, whereas it was $42.6 \%$ among patients who did not conduct internet search for medical information. Having expressed the foregoing, there are various issues to consider about whether the websites over the internet are updated, correct, neutral and comprehensive or how they influence patients.

\section{Conclusion}

As a result, a digital interest that has gradually increased in recent years comes into question when patients desire to have information on the course and treatment of their rheumatic diseases. It should be acknowledged that patients with long-term treatment and followup processes are not and will not be guided only by their doctors. Therefore, it may prevent misinformation and misguidance if these websites are strictly inspected by both the Ministry of Health and relevant associations. Furthermore, physicians may improve the quality of life of their patients and help them avoid unnecessary anxieties, if they regard the foregoing when they inform and instruct them.

\section{Ethics}

Ethics Committee Approval: The study protocol was approved by the İstanbul Medipol University Ethics Committee (decision number: 158, date: 22/02/2019).

Informed Consent: Written consent was not obtained because the detailed medical and identifiable information of patients were not collected.
Peer-review: Externally peer-reviewed.

Authorship Contributions: Surgical and Medical Practices - A.G.A., S.T.; Concept - A.G.A., S.T. ; Design - A.G.A., S.T. ; Data Collection or Processing - A.G.A., S.T. ; Analysis or Interpretation - A.G.A. ; Literature Search A.G.A., S.T. ; Writing - A.G.A.

Conflict of Interest: No conflict of interest was declared by the authors.

Financial Disclosure: The authors declared that this study received no financial support.

\section{References}

1. Zochling J, Smith EU. Seronegative spondyloarthritis. Best Pract Res Clin Rheumatol 2010; 24: 747-56

2. Alamanos Y, Drosos AA. Epidemiology of adult rheumatoid arthritis. Autoimmun Rev 2005; 4: 130-6.

3. Wolfe F, Clauw DJ, Fitzcharles MA, Goldenberg DL, Katz RS, Mease P, et al. The American College of Rheumatology preliminary diagnostic criteria for fibromyalgia and measurement of symptom severity. Arthritis Care Res (Hoboken) 2010; 62: 600-10.

4. Dijilopedi. 2018 Türkiye İnternet Kullanım ve Sosyal Medya İstatistikleri. Available from URL: https://dijilopedi.com/2018-turkiye-internet-kullanimve-sosyal-medya-istatistikleri/ (last accessed 2019 Jan 18), 2018.

5. Dijilopedi. 2018 Internet Kullanım ve Sosyal Medya İstatistikleri. Available from URL: https://dijilopedi.com/2018-internet-kullanimi-ve-sosyal-medyaistatistikleri/ (last accessed 2019 Jan 18), 2018.

6. Eng TR, Maxfield A, Patrick K, Deering MJ, Ratzan SC, Gustafson DH. Access to health information and support: a public highway or a private road? JAMA 1998; 280: 1371-5.

7. Pew Research Center: More online, doing more: 16 million newcomers gain Internet access in the last half of 2000 as women, minorities, and families with modest incomes continue to surge online. Available from URL: https:// www.pewresearch.org/internet/2001/02/18/more-online-doing-more/ (last accessed 2016 June 26), 2001.

8. Grandinetti DA. Doctors and the web: help your patients surf the net safely. Med Econ 2000; 77: 186-8, 194-6, 201.

9. Daraz L, MacDermid JC, Wilkins S, Gibson J, Shaw L. The quality of websites addressing fibromyalgia: An assessment of quality and readability using standardised tools. BMJ Open 2011; 1: e000152.

10. Cline RJ, Haynes KM. Consumer health information seeking on the Internet: The state of the art. Health Educ Res 2001; 16: 671-92.

11. Aletaha D, Neogi T, Silman AJ, Funovits J, Felson DT, Bingham CO 3rd, et al. 2010 Rheumatoid arthritis classification criteria: an american college of rheumatology/european league against rheumatism collaborative initiative. Arthritis Rheum 2010; 62: 2569-81.

12. van der Linden S, Valkenburg HA, Cats A. Evaluation of diagnostic criteria for ankylosing spondylitis: a proposal for modification of the New York criteria. Arthritis Rheum 1984; 27: 361-8.

13. Wolfe F, Smythe HA, Yunus MB, Bennett RM, Bombardier C, Goldenberg DL, et al. The American College of Rheumatology 1990 criteria for the classification of fibromyalgia: report of the Multicenter Criteria Committee. Arthritis Rheum 1990; 33: 160-72.

14. Net Applications. Market Share Statistics for Internet Technologies. Available from: http://www.netmarketshare.com (last accessed 2016 June 26), 2014.

15. Huberman BA, Pirolli PLT, Pitkow JE, Lukose RM. Strong regularities in World Wide Web surfing. Science 1998; 280: 95-7. 
16. Charnock D, Shepperd S, Needham G, Gann R. DISCERN: An instrument for judging the quality of written consumer health information on treatment choices. J Epidemiol Community Health 1999; 53: 105-11.

17. Galvez-Sánchez CM, Duschek S, Reyes del Paso GA. Psychological impact of fibromyalgia: current perspectives. Psychol Res Behav Manag 2019; 12: 117 27.
18. Samanci Y, Celik SE. Low Back Pain and Internet: Infopollution. Turk Neurosurg 2017; 27: 804-8.

19. Atci, IB, Yilmaz, H, Kocaman, U, Samanci MY. An evaluation of internet use by neurosurgery patients prior to lumbar disc surgery and of information available on internet. Clin Neurol Neurosurg 2017; 158: 56-9. 